\title{
PENGEMBANGAN RANCANG BANGUN GAME EDUKASI LOGISTIK "STOWAGAME" MENGENAI PENATAAN KONTAINER DI BAY KAPAL
}

\author{
HENDRIYONO RACHMAN, DAN AHMAD RUSDIANSYAH \\ Jurusan Teknik Industri, Institut Teknologi Sepuluh Nopember (ITS) Surabaya \\ E-mail: arusdian@ie.its.ac.id
}

\begin{abstract}
ABSTRAK
Pengembangan game edukasi yang dibuat fokus pada permasalahan yang terjadi pada manajemen pelabuhan utamanya pada permasalahan loading kontainer di suatu bay kapal. Permasalahan dalam perencanaan loading di bay kapal biasa disebut dengan Master Bay Plan Problem (MBPP). Kompleksitas dari permasalahan MBPP dapat dilihat dari konstrain yang ada, yaitu berat kontainer, tujuan kontainer, ukuran kontainer, tipe kontainer, dan aturan peletakan kontainer. Dalam pembuatan game, studi kasus, aturan permainan dalam pengembangan game ini disesuaikan dengan konteks teori dan juga kondisi nyata yang terjadi pada penataan kontainer di bay kapal. Rancang bangun dari game ini dinamakan StowaGame. StowaGame adalah game edukasi berbasis simulasi terkait dengan penataan kontainer di bay kapal. Perangkat lunak yang dibuat menerjemahkan pengetahuan dari MBBP ditambah unsur hiburan ke dalam aturan game. Untuk menguji keefektifan game edukasi ini, telah dilakukan uji kepada para pemain. Pengetahuan mengenai $M B P P$ dari tester akan diuji sebelum dan sesudah memainkan game. Perhitungan uji paired-t test menghasilkan p-value $<0.05$ sehingga dapat disimpulkan bahwa game edukasi yang dibuat mampu memberikan edukasi yang signifikan terkait dengan penataan kontainer di bay kapal.
\end{abstract}

Kata kunci: game edukasi, master bay plan problem, penataan kontainer

\begin{abstract}
ABTRACT
Development of educational games focuss on the problem occured on bay management, primarily on loading container at ship bay. The loading plan problem in ship bay commonly known as Master Bay Plan Problem (MBPP). The complexity of MBPP can be seen on its constraints, that are container weight, container destination, container size, container type, and the arrangement rule of container. The study case and playing rules in this game development are adjusted to contextual theory and real situation occured in container arrangement at ship bay. The prototype of this game is called StowaGame. StowaGame is a simulation-based educational games related to container arrangement in ship bay. This software are built with the integration of MBPP and entertainment concept. The effectivity of this educational game will be tested by several player. The MBPP concept of each player will be tested before and after playing the game. Paired-t test calculation shows that p-value is less than 0,05. Thus, it can be concluded that the educational game can educate people with container arrangement concept in ship bay.
\end{abstract}

Key words: educational games, master bay plan problem, container arrangement

\section{PENDAHULUAN}

Seiring dengan pesatnya permintaan akan transportasi laut, jasa pengiriman transportasi laut harus berpikir keras untuk meningkatkan efisiensi sehingga dapat meningkatkan daya saing terhadap jasa transportasi lain. Untuk mencapai hal tersebut, perlu adanya pengetahuan dan pemahaman terhadap perkembangan ilmu dan teknologi yang terkait. Akademisi dapat berperan aktif untuk memberikan kontribusi berupa transfer ilmu terhadap jasa transportasi laut. Salah satu metode transfer ilmu yang dapat dilakukan adalah menggunakan game edukasi.
Game edukasi berbasis simulasi didesain untuk mensimulasikan permasalahan yang ada sehingga diperoleh esensi atau ilmu yang dapat digunakan untuk menyelesaikan permasalahan tersebut. Game simulasi dengan tujuan edukasi ini dapat digunakan sebagai salah satu media edukasi yang memiliki pola pembelajaran learning by doing. Berdasarkan pola yang dimiliki oleh game tersebut, pemain dituntut untuk belajar sehingga dapat menyelesaikan permasalahan yang ada. Status game, instruksi, dan tools yang disediakan oleh game akan membimbing pemain secara aktif untuk menggali informasi sehingga dapat memperkaya pengetahuan dan strategi saat bermain. 
Game edukasi sangat menarik untuk dikembangkan. Ada beberapa kelebihan dari game edukasi dibandingkan dengan metode edukasi konvensional. Salah satu kelebihan utama game edukasi adalah pada visualisasi dari permasalahan nyata. Massachussets Insitute of Technology (MIT) berhasil membuktikan bahwa game sangat berguna untuk meningkatkan logika dan pemahaman pemain terhadap suatu masalah melalui proyek game yang dinamai Scratch (http://scratch.mit.edu). Berdasarkan hasil penelitian-penelitian sebelumnya, telah dibuktikan game edukasi dapat menunjang proses pendidikan (Marsh, et al., 2005; Clark, 2006).

Game edukasi unggul dalam beberapa aspek jika dibandingkan dengan metode pembelajaran konvensional. Salah satu keunggulan yang signifikan adalah adanya animasi yang dapat meningkatkan daya ingat sehingga siswa dapat menyimpan materi pelajaran dalam waktu yang lebih lama dibandingkan dengan metode pengajaran konvensional (Clark, 2006). Unsur lain yang dimasukkan dalam game yang dibuat adalah hiburan. Dengan adanya hiburan, diharapkan proses belajar dapat lebih menyenangkan sehingga siswa dapat belajar dengan lebih efektif. Learning is most effective when it is fun (Loomans and Kohlberg, 1993).

Pada penelitian ini, pengembangan game edukasi akan fokus pada permasalahan loading kontainer di suatu bay kapal. Permasalahan yang dihadapi dalam perencanaan loading di kapal biasa disebut dengan Master Bay Plan Problem (MBPP) atau Stowage Planning Problem (SPP). Kompleksitas dari permasalahan MBPP dapat dilihat dari konstrain yang ada, yaitu berat kontainer, tujuan kontainer, ukuran kontainer, tipe kontainer, dan aturan peletakan kontainer.

Pada praktek di lapangan, penempatan kontainer pada suatu bay kapal ditentukan oleh pangkalan kapal yang berkolaborasi dengan pekerja yang bertanggung jawab atas peletakan kontainer pada kapal yang dimaksud. Dengan berpedoman pada rancang bangun bay kapal, pekerja tersebut dapat menentukan peletakan kontainer yang sesuai dengan tipenya yang beragam. Perencanaan ini bertujuan untuk mengedukasi pemain sehingga dapat meminimasi terjadinya shifting pada kontainer yang tidak dibongkar di pelabuhan berikutnya. Agar keputusan yang diambil tepat, pengalaman dan pengetahuan yang tinggi adalah hal yang mutlak harus dimiliki oleh pekerja. Metode optimasi untuk meminimasi jumlah shifting kontainer telah dibahas oleh beberapa peneliti sebelumnya, misalnya Ambrosino et al., (2004).
Penelitian ini secara spesifik akan menfokuskan pada penterjemahan pengetahuan-pengetahuan mengenai MBPP atau SPP ke dalam suatu game edukasi yang dapat menjadi media latihan dan pembelajaran mengenai permasalahan penataan kontainer di bay kapal. Game ini kemudian dinamakan StowaGame.

\section{PERANCANGAN GAME}

\section{Konsep Dasar}

StowaGame dibuat untuk digunakan untuk mahasiswa yang mendalami bidang manajemen logistik dan manajemen rantai pasok (supply chain management). StowaGame dirancang untuk dapat mensimulasikan suatu kondisi permasalahan yang terjadi dalam penataan kontainer di bay kapal. Pemain diharuskan untuk menyelesaikan dan memberikan solusi terhadap permasalahan tersebut. StowaGame dirancang sedemikian rupa sehingga dapat membangun pemikiran heuristik dari pemain sehingga dapat mengembangkan imajinasi dan membangun pemikiran secara sistemik terhadap permasalahan SPP sehingga dapat dicari solusi yang diterapkan. Titik berat dari perancangan StowaGame adalah untuk memberikan pengalaman dalam menghadapi suatu permasalahan dan mencoba mencari solusi terhadap permasalahan tersebut.

Dengan adanya simulasi dalam game yang dibuat, pemain dihadapkan pada permasalahan penataan kontainer yang relatif mirip dengan keadaan sebenarnya. Misalnya, pemain akan mengetahui bagaimana penataan kontainer atau box untuk kapal atau kendaraan multi tujuan. Dalam hal ini, pengajar akan berperan sebagai pendamping dan pemain akan berperan aktif dalam usahanya menyelesaikan permasalahan yang ada.

Unsur pedagogis adalah salah satu dari unsur yang terdapat pada konsep dari StowaGame. Pedagogis yang dimaksud disini adalah terjadinya student-centered learning sehingga siswa yang akan mencari tahu apa permasalahan yang terjadi dan bagaimana solusinya. Dalam menjalankan permainan, rancangan penataan kontainer yang diberikan oleh pemain dievaluasi oleh game secara terus menerus. Game akan memberikan informasi mengenai status dari kontainer yang telah ditata pada bay kapal.

Evaluasi yang dilakukan oleh game adalah waktu yang dibutuhkan dalam menyelesaikan permasalahan, benar atau tidaknya penataan, dan jumlah unnecessary shifting yang terjadi. Evaluasi yang diberikan oleh game akan memberikan umpan 
balik kepada pemain sehingga pemain dapat mengerti kesalahan yang dilakukan sehingga pemain dapat memperbaiki kesalahannya.

Selain itu, hal lain yang terkandung dalam StowaGame ini adalah adanya unsur hiburan dalam rancangan user interface. Dengan adanya unsur hiburan yang terkandung di dalam game ini, pemain diharapkan lebih mampu menyerap informasi yang disampaikan. Salah satu keuntungan lain dari adanya unsur hiburan adalah pemain tidak akan cepat bosan dalam menerima informasi yang akan diberikan.

\section{Simplifikasi}

StowaGame ini dirancang untuk menyerupai permasalahan nyata dari penataan kontainer di bay kapal menjadi suatu permasalahan yang relatif lebih simpel namun tidak meninggalkan aspek-aspek sebenarnya dari penataan kontainer. Tujuan dari simplifikasi dari permasalahan nyata tersebut adalah untuk lebih mempermudah penjelasan dan transfer pengetahuan dari pembuat game terhadap pemain game. Simplifikasi dari permasalahan tersebut juga dapat digunakan untuk memudahkan pemrograman dari game. Simplifikasi dari permasalahan penataan kontainer dalam game ini antara lain adalah dimensi bin-packing, pemindahan kontainer yang telah diletakkan, dan parameter yang menyebabkan terjadinya kemiringan dari kapal.

Permasalahan penataan kontainer di bay kapal adalah permasalahan bin-packing tiga dimensi yang terdiri dari dimensi bay, tier, dan row. Dalam game yang dibuat, permasalahan penataan kontainer tersebut disimplifikasikan menjadi permasalahan binpacking dua dimensi yang hanya terdiri dari dimensi tier dan row. Dalam hal ini dimensi bay masih terlibat di dalam permasalahan game yaitu sebanyak satu bay namun ukuran panjang kontainer adalah sama dengan panjang bay yang mengakibatkan dimensi bay menjadi tidak perlu diperhitungkan. Simplifikasi dari dimensi permasalahan bin-packing dapat dilihat pada gambar 1.

Simplifikasi lain yang terdapat dalam game ini yaitu kontainer yang telah diletakkan di suatu slot pada bay kapal tidak boleh dipindahkan ke slot lain. Hal ini dimaksudkan untuk meningkatkan tantangan yang ada. Jika pemain melakukan kesalahan peletakan kontainer, pemain dapat memanfaatkan fasilitas undo last move yang disediakan dalam game. Fasilitas ini dapat digunakan berkali-kali tetapi hanya berlaku untuk undo satu langkah terakhir saja.

Simplifikasi yang terakhir yaitu parameter yang menyebabkan terjadinya kemiringan kapal.

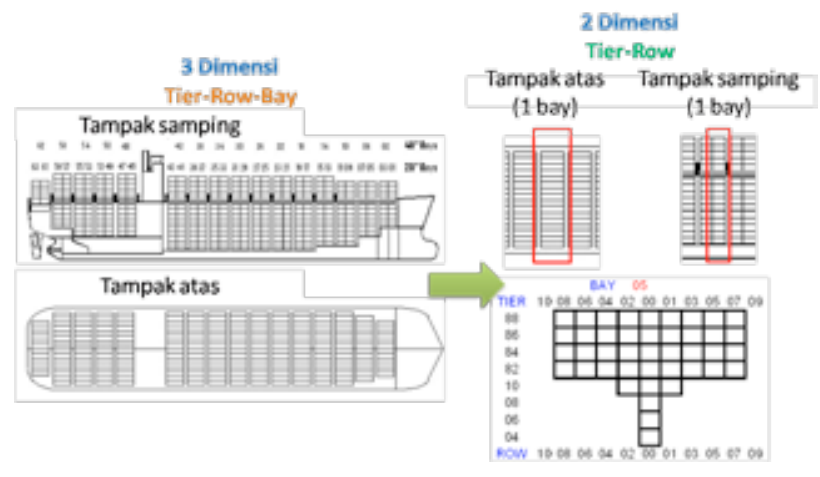

Gambar 1. Simplifikasi Dimensi Bin-Packing

Kemiringan kapal dapat terjadi akibat selisih berat, ballast air, meta center, dan toleransi dari masingmasing kapal. Batas maksimum kemiringan kapal umumnya adalah \pm 15 derajat dari titik normal. Kemiringan kapal adalah positif jika searah dengan jarum jam dan negatif jika berlawanan dengan arah jarum jam. Dalam game ini, parameter yang menyebabkan terjadinya kemiringan kapal adalah toleransi dari kapal dan selisih berat saja. Simplifikasi dari parameter kemiringan kapal dapat dilihat pada gambar 2.
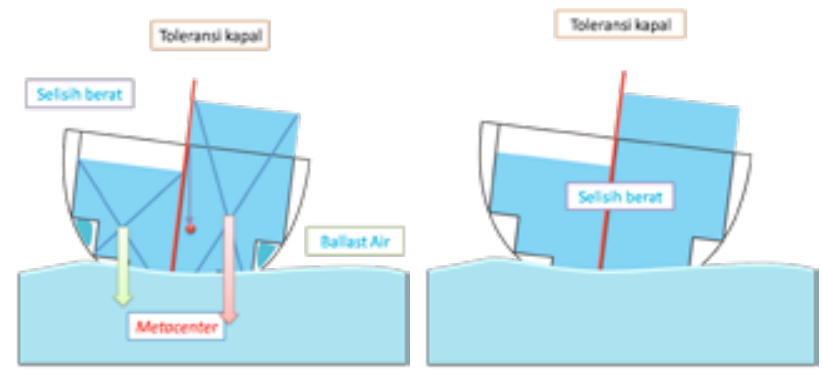

Gambar 2. Simplifikasi dari Parameter Penyebab Kemiringan Kapal

Pemain dihadapkan pada penataan sejumlah kontainer yang telah ditentukan sedimikian rupa sehingga tidak ada unnecessary shifting dari kontainer di yard dalam penataannya ke dalam bay kapal. Pemain harus mengambil kontainer yang terletak di bagian paling atas dari tumpukan kontainer yang ada. Dalam hal ini, selain variabel-variabel yang melingkupi penataan itu sendiri, ada variabel lain yang berupa limit waktu. Dengan adanya limit waktu tersebut maka penataan kontainer harus dilaksanakan tidak melebihi waktu yang telah ditentukan.

Pemainjuga akan dihadapkan pada permasalahan kapal direct dan kapal feeder. Pemain akan menata kontainer untuk satu, dua atau tiga tujuan sesuai dengan tahapan kesulitan yang telah ditentukan. 
Untuk penataan kontainer lebih dari satu tujuan, pemain harus memenuhi batasan unnecessary shifting maksimum yang diperbolehkan.

Selama permainan berlangsung, pemain akan diberikan status penataan dan list kontainer yang masih tersedia. Status penataan yang dimaksud adalah kemiringan kapal, berat di kiri dan kanan kapal, tinjauan hasil penataan (untuk semua variabel) dan waktu yang tersedia.

\section{Rancangan Cerita}

Game edukasi berbasis simulasi harus memiliki cerita game yang sangat kuat di mana pemain yang awam (tidak memiliki dasar pengetahuan terhadap permasalahan) dapat mengerti permasalahan yang ada dengan adanya tuntunan dari cerita game. Salah satu kekuatan utama dari edukasi adalah cerita game.

Cerita game tersebut harus dibuat semenarik dan sejelas mungkin agar pemain dapat mengerti apa yang harus dilakukan olehnya untuk menyelesaikan permasalahan yang ada dengan bantuan dan supervisi yang minimal dari orang lain atau tutor. Cerita game disini harus menarik agar pemain tidak bosan membaca tiap kalimat yang ada dalam cerita game. Penjelasan terhadap masalah yang ada juga harus dimasukkan dalam cerita game tersebut.

Beberapa hal yang dimasukkan dalam cerita game tersebut adalah:

1. Langkah-langkah permainan

2. Kontrol permainan

3. Cerita singkat permasalahan (overview)

4. Cerita detail permasalahan

Cerita dari game tersebut akan dimunculkan dengan menyesuaikan terhadap kebutuhan dari pemain. Cerita singkat permasalahan, langkahlangkah penyelesaian serta kontrol permainan akan dijelaskan pada awal permainan sedangkan cerita detail permasalahan akan dimunculkan pada tiap awal level. Hal ini dimaksudkan agar pemain dapat mencerna informasi dan pengetahuan yang diberikan dengan mudah. Informasi mengenai penataan dari kontainer tidak dijelaskan sekaligus tetapi menyesuaikan dengan desain dari level yang telah ditentukan. Hal ini dimaksudkan agar pemain dapat mengingat dan memahami dengan mudah informasi yang diperoleh.

\section{Rancangan Evaluasi Terhadap Pemain}

Pemain akan diberikan feedback jika gagal dalam menyelesaikan suatu permasalahan. Feedback ini akan diberikan secara otomatis dan disesuaikan dengan kesalahan yang dilakukan oleh pemain.
Pemain dapat memahami kesalahannya dan menggunakan saran yang dihasilkan oleh sistem dalam usahanya untuk menyelesaikan permasalahan yang ada. Saran yang dibuat bersifat general terhadap kesalahan atau permasalahan yang dihadapi.

\section{Rancangan Level Permainan}

Desain level yang baik mutlak harus dimiliki oleh sebuah game edukasi. Dengan desain level yang baik, pemain akan lebih mudah dalam memahami permasalahan yang ada. Level itu sendiri dapat diartikan sebagai tahapan edukasi, mulai dari yang paling mudah sampai ke tingkat yang tersulit dalam game. Jika desain level tersebut tidak diatur dengan baik, alurnya melompat-lompat atau tidak menyesuaikan dengan tingkat pemahaman dari pemain, pemain akan kesulitan menangkap informasi yang diberikan oleh game. Desain level dari game yang akan dibuat dengan mempertimbangkan variabel penataan dan tingkat kesulitan dari penataan kontainer di bay kapal dapat dilihat pada tabel 1.

Tabel 1. Desain Level Permainan

\begin{tabular}{|c|c|c|c|c|c|}
\hline \multirow{3}{*}{ Level } & \multicolumn{5}{|c|}{ Konstrain } \\
\hline & \multicolumn{4}{|c|}{ Kontainer } & \multirow{2}{*}{$\begin{array}{c}\text { Kapal } \\
\text { Kese- } \\
\text { imbangan }\end{array}$} \\
\hline & Tujuan & Tipe & Ukuran & Berat & \\
\hline \multicolumn{6}{|l|}{ Pemula } \\
\hline Level 1 & Satu tujuan & 3 & $20^{\prime \prime}$ & $\mathrm{x}$ & $\mathrm{x}$ \\
\hline Level 2 & Satu tujuan & 3 & $20^{\prime \prime}$ & $\tilde{\mathbf{N}}$ & $\mathrm{x}$ \\
\hline Level 3 & Satu tujuan & 3 & $20^{\prime \prime}$ & $\tilde{\mathrm{N}}$ & $\tilde{\mathbf{N}}$ \\
\hline Level 4 & Satu tujuan & 3 & $20^{\prime \prime}$ dan $40^{\prime \prime}$ & $\tilde{\mathrm{N}}$ & $\tilde{\mathrm{N}}$ \\
\hline \multicolumn{6}{|c|}{ Menengah } \\
\hline Level 5 & Dua tujuan & 3 & $20^{\prime \prime}$ & $\tilde{\mathrm{N}}$ & $\tilde{\mathrm{N}}$ \\
\hline Level 6 & Dua tujuan & 3 & $20^{\prime \prime}$ & $\tilde{\mathbf{N}}$ & $\tilde{N}$ \\
\hline Level 7 & Tiga tujuan & 3 & $20^{\prime \prime}$ dan $40^{\prime \prime}$ & $\tilde{\mathrm{N}}$ & $\tilde{\mathbf{N}}$ \\
\hline
\end{tabular}

Desain level tersebut juga dibagi menjadi dua tingkat kesulitan utama yaitu pemula dan menengah. Tingkat kesulitan tersebut dibagi berdasarkan pada tujuan dari kontainer. Tingkat kesulitan pemula adalah penataan kontainer untuk satu tujuan sedangkan tingkat kesulitan menengah adalah penataan kontainer untuk lebih dari satu tujuan. Adanya perbedaan tingkat kesulitan tersebut adalah dikarenakan ada parameter penilaian tambahan pada penataan kontainer lebih dari satu tujuan yaitu unnecessary shifting.

\section{PENGEMBANGAN PERANGKAT LUNAK}

Perangkat lunak game edukasi ini dibuat pada platform. Net Framework + XNA dengan bahasa pemrograman $\mathrm{C} \#$ atau dengan kata lain adalah 
sebuah game yang dapat dijalankan pada komputer yang berbasis Windows.

\section{Rancangan Input Game}

Kontainer yang berada di lapangan kontainer (container yard) di pelabuhan yang akan dipindahkan ke bay kapal dirancang tetap. Pemilihan sifat list kontainer yang tetap ini (tidak acak) dikarenakan agar permasalahan dari penataan kontainer tersebut dapat diperbandingkan antara pemain satu dengan pemain lainnya. Selain itu, penataan kontainer yang bersifat acak akan jauh lebih sulit dalam pemrogramannya karena penataan kontainer di yard itu juga memiliki aturan penataan kontainer. Set dari kontainer yang terdapat di yard sudah diatur sebelumnya. Terdapat beberapa set permasalahan penataan dibuat. Masing-masing set permasalahan kontainer tersebut sudah dilengkapi dengan lima variabel yang terkait dengan penataan kontainer. Contoh dari set penataan di lapangan kontainer yang merupakan input dari permainan dapat dilihat di gambar 3 .

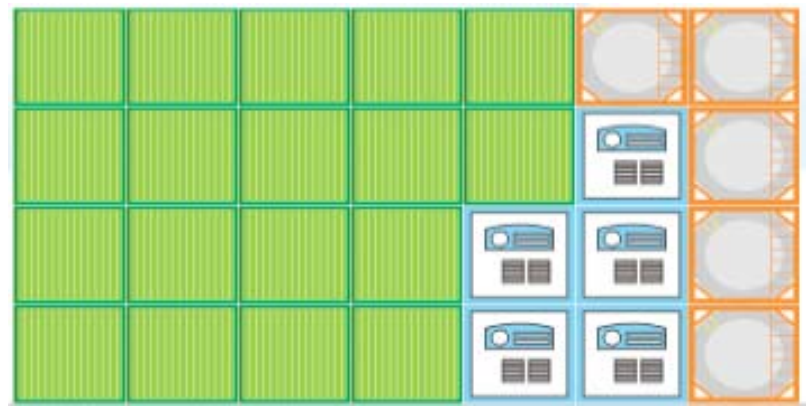

Gambar 3. Penataan di Lapangan Kontainer sebagai Input Permainan

\section{Rancangan Komponenen Pendukung Game}

Komponen pendukung dalam game adalah desain gambar, suara, dan cerita game, yang dapat membantu penyampaian informasi dari game terhadap pemain. Bahan pendukung yang dimaksud memiliki fungsi utama yaitu untuk tambahan knowledge atau entertainment saja. Bahan pendukung ini utamanya adalah kosmetik dalam game namun hal ini adalah salah satu hal penting yang tidak boleh diremehkan karena adanya desain yang menarik dapat meningkatkan minat dari pemain game dan dapat memperlambat munculnya kebosanan. Desain pendukung utama dari game yang dibuat adalah desain bay dan bentuk kapal, desain background, dan desain tipe kontainer. Bahan pendukung dari game tidak hanya tampilan dari game tetapi juga suara dan animasi dari game.

\section{Rancangan Menu Game}

Menu game adalah tampilan utama dari game yang dimainkan. Menu game yang ditampilkan berisi tentang new game, controls, introduction, game story, dan exit game. Desain tampilan menu game dapat dilihat pada gambar 4 .

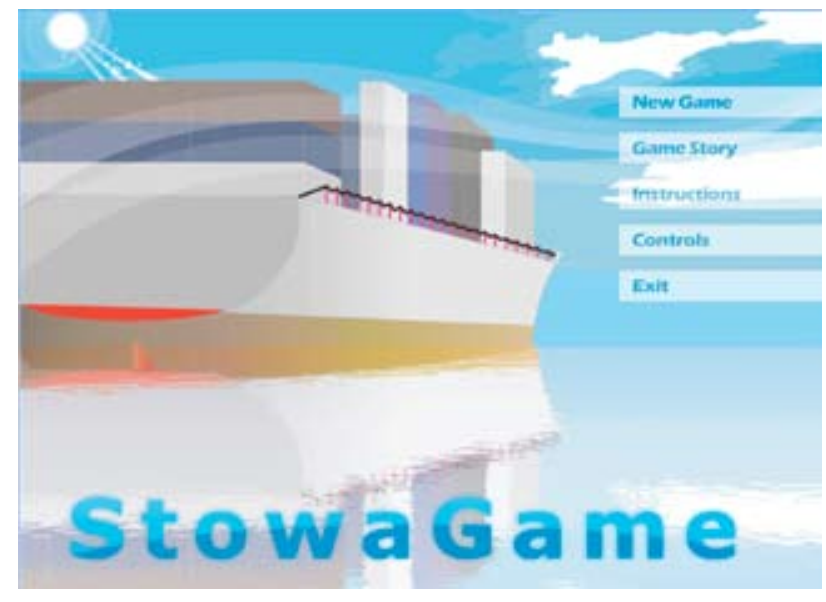

Gambar 4. Desain Menu Game

\section{Rancangan Bay dan Bentuk Kapal}

Ada tiga kapal yang dapat dimainkan oleh pemain. Masing-masing kapal memiliki perbedaan desain bay dan bentuk kapal. Dengan adanya perbedaan bay dan bentuk kapal yang telah dijelaskan sebelumnya, maka perlu adanya desain yang berbeda dari masing-masing kapal untuk memperjelas perbedaan dari masing-masing kapal. Adanya perbedaan bentuk bay dalam desain kapal tidak memengaruhi tingkat kesulitan dari penataan secara signifikan. Adanya beberapa bentuk bay dan kapal hanya dimaksudkan untuk memperkaya konten dari game yang dikembangkan. Desain dari bay dan bentuk kapal dapat dilihat pada gambar 5 .

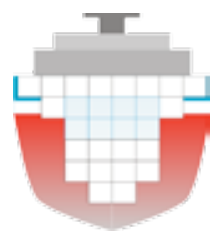

(a) Tipe kapal 1

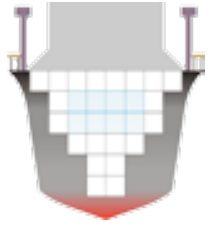

(b) Tipe kapal 2

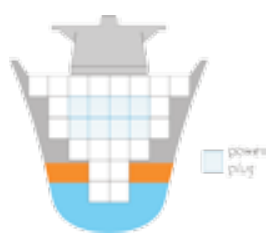

(c) Tipe kapal 3
Gambar 5. Rancangan Bay dan Bentuk Kapal

\section{Rancangan Background Dari Pelabuhan}

Kapal memiliki tiga buah tujuan pelabuhan yaitu Singapura, Yokohama, dan Surabaya. Tujuan dari pelabuhan kapal tersebut akan diinformasikan terhadap pemain dalam cerita game yang dibuat. Rute dari kapal dapat dilihat pada gambar 6 . 


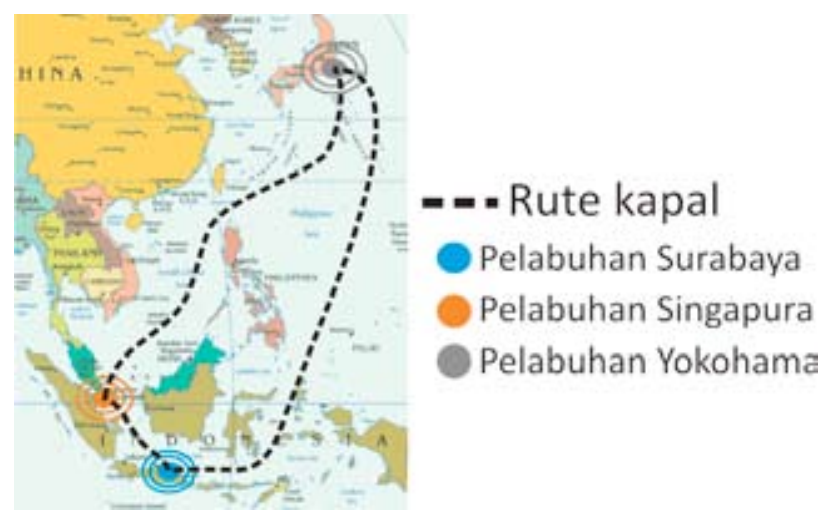

Gambar 6. Tujuan Kapal

Pemain akan mulai memainkan game pada pelabuhan di kota Surabaya. Urutan dari pelabuhan tujuan default-nya adalah Surabaya - Singapura Yokohama. Urutan ini pada suatu saat akan berganti sesuai dengan level dari permainan yang telah dicapai oleh pemain. Background dari pelabuhan tujuan dari kapal dibuat sesuai dengan persepsi dari peneliti terhadap pelabuhan tujuan yang disesuaikan dengan kondisi pelabuhan sebenarnya. Desain background dibuat semenarik mungkin tujuannya agar dapat membuat pemain tertarik untuk memainkan game ini. Background ini digunakan sebagai gambar yang merepresentasikan keadaan pelabuhan di tempat tujuan. Desain background pelabuhan dapat dilihat pada gambar 7 .

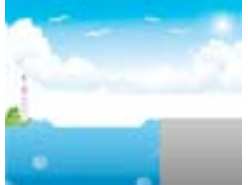

(a) Background pelabuhan

Surabaya

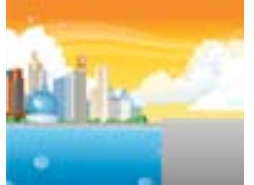

(b) Background pelabuhan Singapura

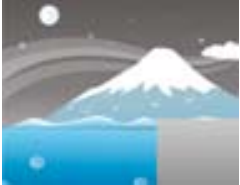

(c) Background pelabuhan Yokohama
Gambar 7. Desain Background Pelabuhan

\section{Rancangan Kontainer}

Variabel yang terkait dengan kontainer ada empat macam yaitu tipe, ukuran, berat, dan tujuan. Masing-masing informasi tersebut akan digambarkan dalam game sesuai dengan variabel yang terlibat pada masing-masing kontainer. Pemain juga akan diberikan informasi tersebut sesuai dengan kontainer yang dipilih.

\section{Desain Informasi Tipe Kontainer}

Tipe kontainer yang terlibat dalam permasalahan penataan adalah kontainer dengan tipe $d r y$, thermal, dan tank. Tipe kontainer tersebut harus direpresentasikan dengan gambar yang sesuai. Desain kontainer yang dibuat disesuaikan dengan tipe kontainer dan bentuk kontainer sebenarnya. Desain tipe kontainer dapat dilihat pada gambar 8 .

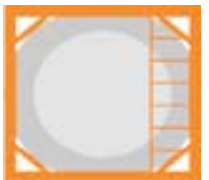

(a) Tank

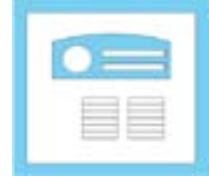

(b) Thermal

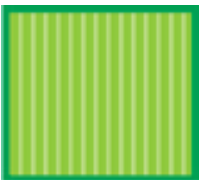

(c) Dry
Gambar 8. Desain Tipe Kontainer

\section{Desain Informasi Kelas Bobot Kontainer}

Kelas bobot dari kontainer yang terlibat dalam permasalahan penataan adalah kelas light, medium, dan heavy. Informasi dari kelas berat sebuah kontainer direpresentasikan dengan gambar yang sesuai. Desain informasi berkenaan dengan kelas berat kontainer dapat dilihat pada gambar 9 .

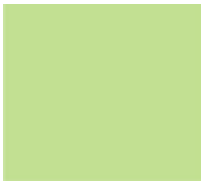

(a) Light

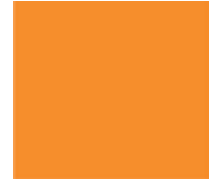

(b) Medium

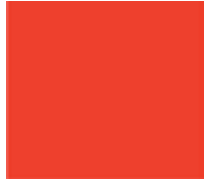

(c) Heavy
Gambar 9. Desain Kelas Bobot Kontainer

\section{Desain Informasi Ukuran Kontainer}

Ukuran dari kontainer yang terlibat dalam permasalahan penataan di penelitian ini adalah kontainer dengan ukuran 20 feet dan 40 feet. Informasi dari ukuran sebuah kontainer direpresentasikan dengan gambar yang sesuai. Desain informasi berkenaan dengan ukuran kontainer dapat dilihat pada gambar 10.

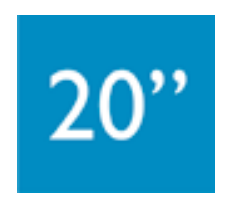

(a) Kontainer 20 feet

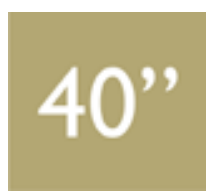

(b) Kontainer 40 feet
Gambar 10. Desain Informasi Ukuran Kontainer

\section{Desain Informasi Tujuan Kontainer}

Tujuan dari kontainer yang terlibat dalam permasalahan penataan di penelitian ini adalah kontainer dengan tujuan Jepang, Surabaya, dan Singapura. Informasi dari tujuan kontainer direpresentasikan dengan gambar yang sesuai. Desain informasi berkenaan dengan tujuan kontainer dapat dilihat pada gambar 11. 


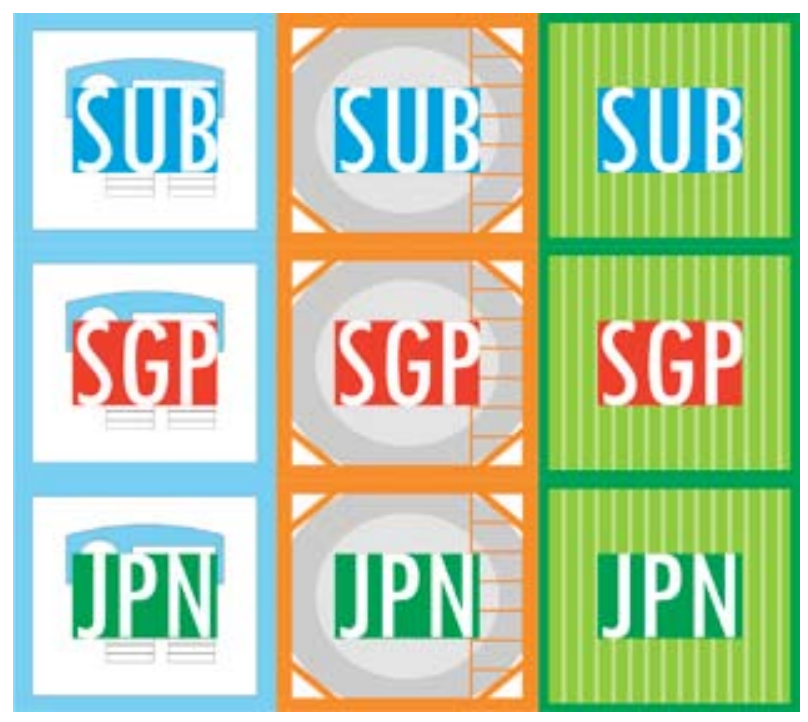

Gambar 11. Desain Informasi Tujuan Kontainer

\section{Desain Informasi Kontainer Terpilih}

Sistem game akan memberikan informasi dari kontainer yang dipilih atau ditunjuk oleh kursor mouse. Dibandingkan dengan desain informasi sebelumnya yang menjelaskan masing-masing state dari variabel yang ada, informasi ini akan menjelaskan secara rinci variabel state yang terlibat dari kontainer yang ditunjuk oleh kursor. Desain informasi kontainer terpilih dapat dilihat pada gambar 12.

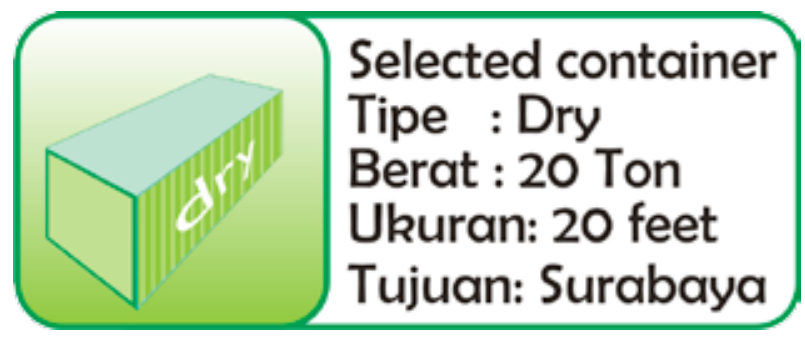

Gambar 12. Desain Informasi Variabel Kontainer Keseluruhan

Dalam contoh gambar di atas, kontainer yang ditunjukkan adalah kontainer $d r y$. Pada game yang dikembangkan, semua tipe kontainer yaitu $d r y$, thermal dan tank akan ditunjukkan dan digambarkan. Informasi dari tipe, berat, ukuran dan tujuan dari kontainer disesuaikan dengan aturan variabel dalam level dan kontainer yang dipilih oleh pemain.

\section{Rancangan Informasi Peletakan Kontainer}

Kontainer yang terpilih dan akan diletakkan di kapal akan diberikan dapat menghasilkan dua keputusan yaitu boleh ditaruh atau tidak boleh ditaruh. Sistem dari game akan menghasilkan keputusan terkait dengan peletakan kontainer oleh pemain. Pemain akan diberikan informasi terkait keputusan tersebut dengan gambar yang sesuai (gambar 13). Kursor dari kontainer akan berwarna hijau jika pemain meletakkan kontainer sesuai dengan batasan yang ada dan kursor akan berwarna merah jika pemain meletakkan kontainer tidak mengikuti batasan yang ada.
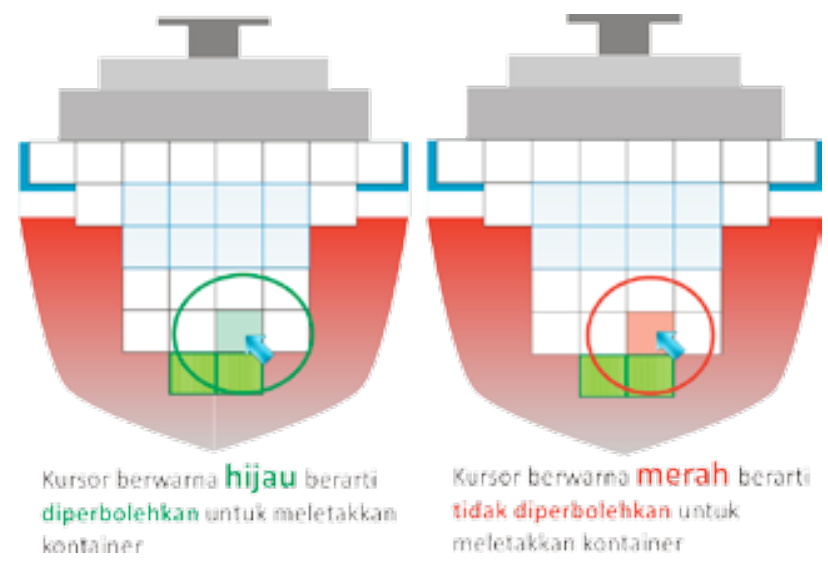

Gambar 13. Desain Informasi Variabel Kontainer Keseluruhan

\section{Rancangan Cerita Game}

Cerita game dibuat dalam bahasa Indonesia. Cerita game ditampilkan secara menyeluruh pada menu utama dan ditampilkan secara bertahap untuk tiap-levelnya. Cerita game disesuaikan dengan batasan dan informasi yang terdapat di dalam permasalahan yang diangkat pada tiap levelnya. Introduksi dari game juga dijelaskan dalam cerita game. Introduksi dari game umumnya berisi overview dan langkah-langkah permainan dalam game.

\section{Rancangan Aturan Permainan}

\section{Menu Pemilihan Kapal}

Bentuk kapal dan level permulaan dapat dipilih sesuai dengan keinginan dari pemain. Bentuk kapal yang tersedia ada tiga bentuk kapal dengah tujuh level yang dapat dipilih. Implementasi dari menu pemilihan kapal dapat dilihat pada gambar 15. 


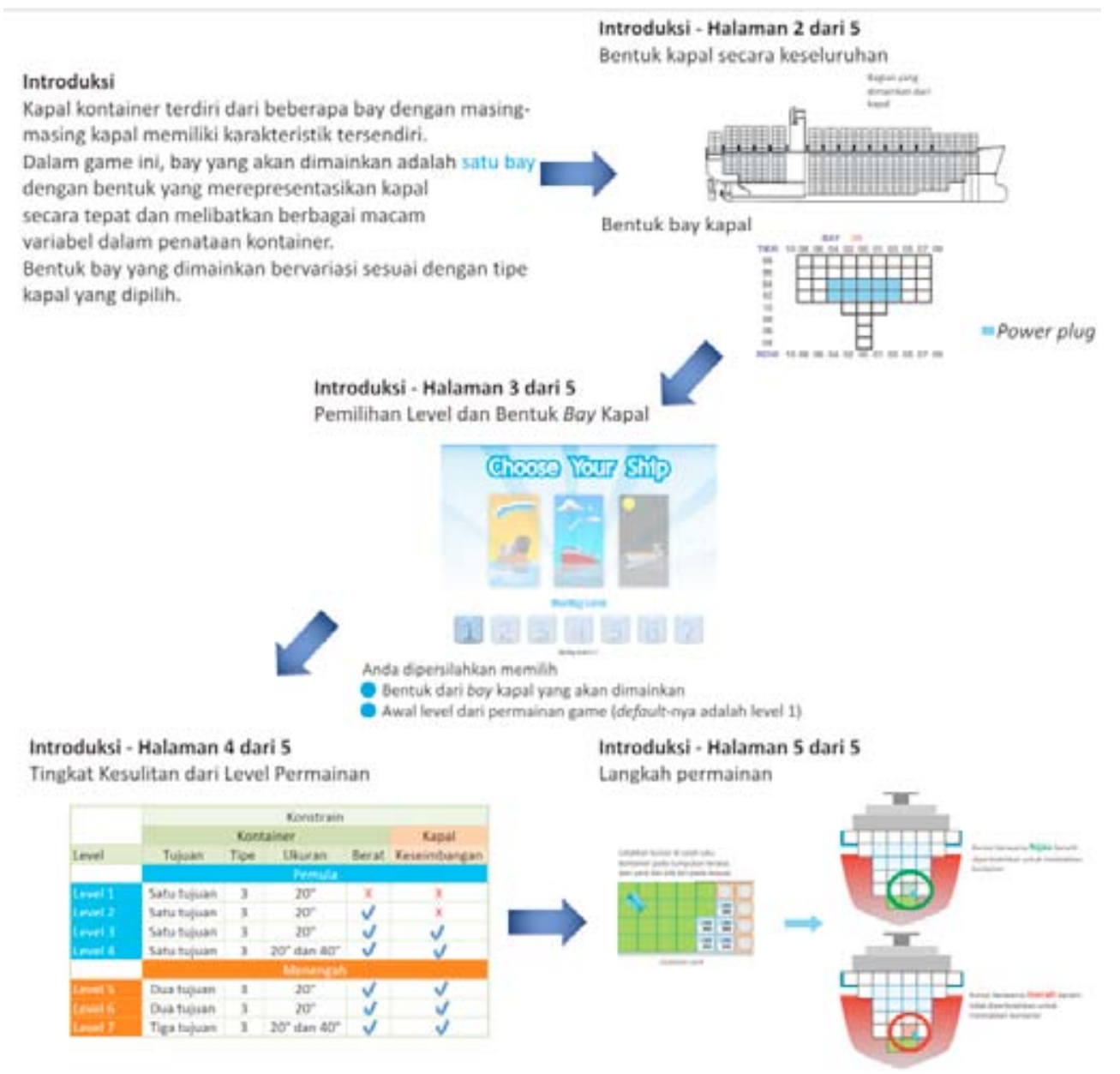

Gambar 14. Cerita Introduksi Game

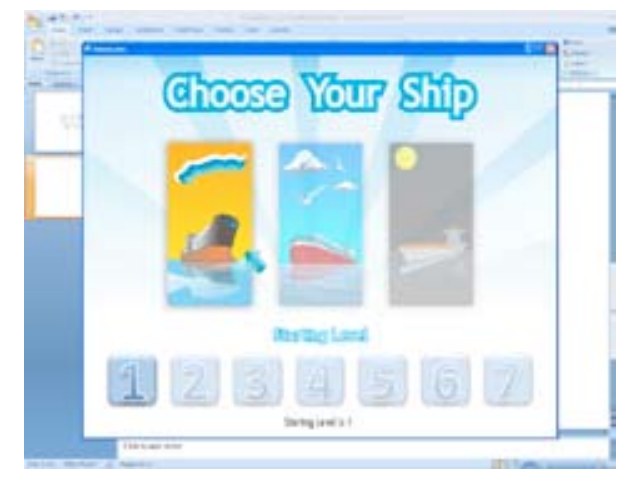

Batasan dari kontainer yang dapat dipilih adalah kontainer tersebut ada di atas tumpukan kontainer yang berada di yard. Pemain tidak diperbolehkan untuk memilih kontainer yang terletak di bagian tengah atau bagian bawah dari tumpukan. Implementasi dari aturan pemilihan kontainer dapat dilihat pada gambar 16 .

Gambar 15. Menu Pemilihan Kapal

Pemain dapat memilih untuk memulai game pada salah satu dari tujuh level yang tersedia. Default dari level permulaan dari game adalah level satu.

\section{Aturan Pemilihan Kontainer}

Kontainer yang terdapat di yard dapat dipilih oleh pemain untuk dimasukkan ke bay kapal.

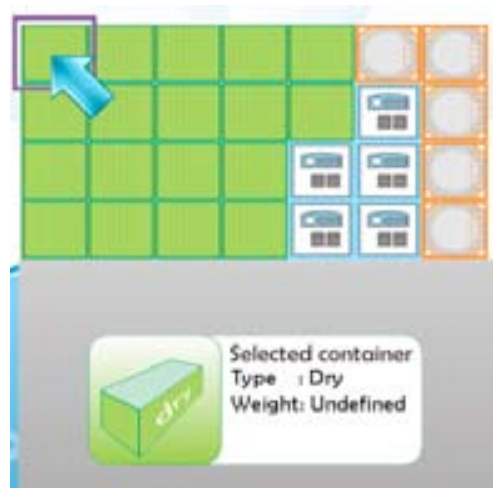

Gambar 16. Pemilihan Kontainer 
Kontainer yang dipilih oleh pemain akan diberi sebuah kotak untuk menandai bahwa pemain telah memilih sebuah kontainer. Pemain dapat melakukan cancel terhadap pemilihan dari kontainer dengan tombol yang telah dijelaskan pada menu kontrol. Jika pemain tidak memilih kontainer yang berada di tumpukan kontainer maka hal tersebut tidak akan dijinkan oleh sistem.

\section{Aturan Penataan Kontainer Berdasarkan Tipe}

Kontainer yang telah dipilih oleh pemain harus ditata sesuai dengan aturan tipe dari kontainer. Kontainer thermal harus diletakkan di lokasi bay yang memiliki power plug (gambar 17), kontainer tank tidak boleh ditumpuk dengan kontainer lain (gambar 18) dan kontainer dry boleh diletakkan di mana saja di lokasi bay kapal (gambar 19).

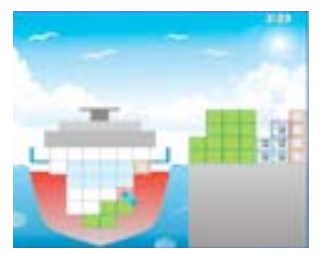

(a) Kontainer thermal diletakkan di bay kapal yang tidak memiliki power plug

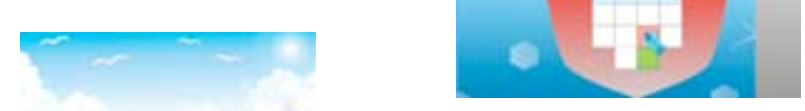

(a) Peletakan yang salah
Implementasi aturan penataan kontainer adalah dasar awal dari penataan kontainer di bay kapal yang berhubungan dengan level atau tingkat kesulitan penataan selanjutnya.

\section{Aturan Penataan Kontainer Berdasarkan Bobot}

Penempatan kontainer harus memperhatikan kontainer di bawahnya. Kontainer yang ditumpuk harus memiliki kelas bobot yang sama atau lebih tinggi dari kontainer di atasnya. Jika hal tersebut tidak dipatuhi maka sistem game akan melarang penempatan kontainer tersebut (gambar 20).

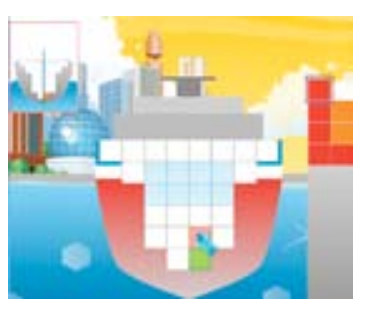

Gambar 20. Aturan Penataan Berdasarkan Bobot
Gambar 20a tersebut menunjukkan bahwa (b) Kontainer thermal diletakkan di bay kapal yang memiliki power plug
Gambar 17. Penataan Kontainer Thermal

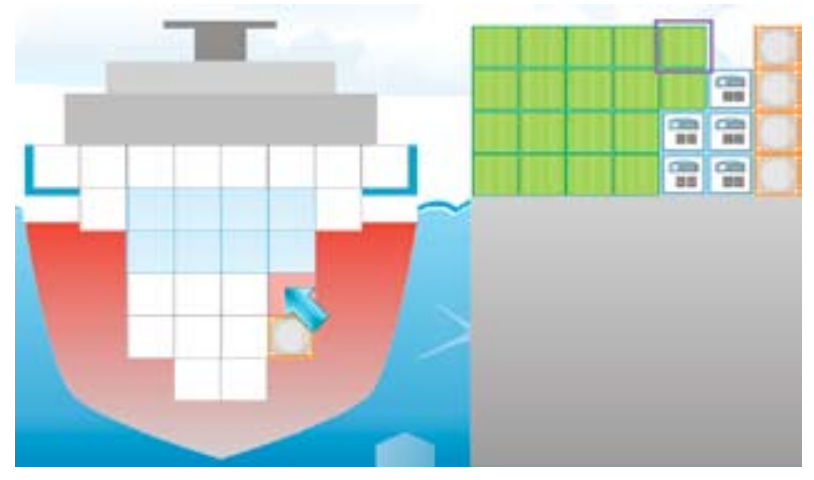

Gambar 18. Penataan Kontainer Tank

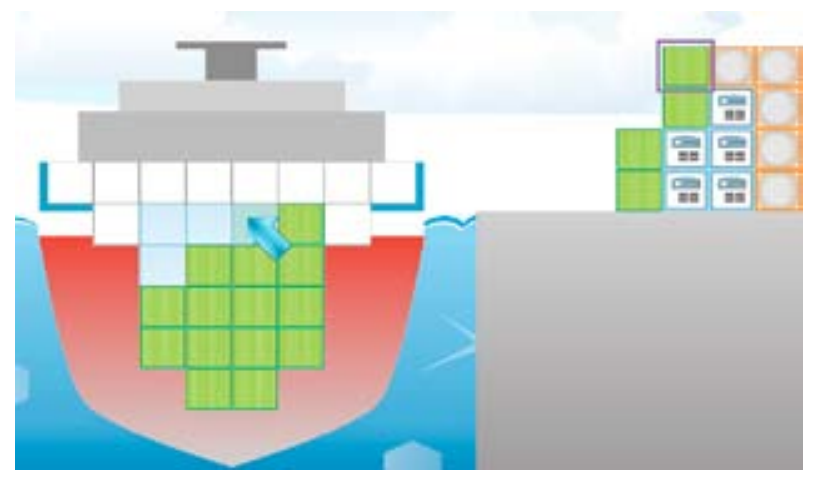

Gambar 19. Penataan Kontainer Dry

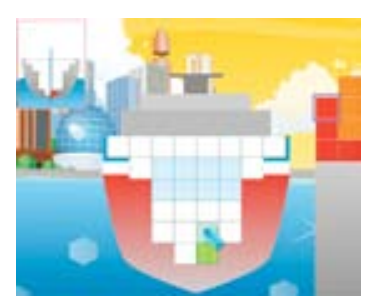

(b) Peletakan yang benar kontainer dengan kelas bobot heavy tidak diperbolehkan untuk diletakkan di atas kontainer dengan kelas bobot medium sedangkan gambar 4.20b menunjukkan sebuah peletakan yang benar di mana kontainer dengan kelas bobot heavy diletakkan di atas kontainer dengan kelas berat yang sama.

\section{Aturan Penataan Kontainer Berdasarkan Ukuran}

Ukuran 20 feet dan 40 feet yang terdapat dalam permasalahan penataan diletakkan sesuai dengan aturan yang berlaku. Kontainer dengan ukuran 40 feet tidak diperbolehkan untuk diletakkan di atas kontainer dengan ukuran 20 feet tetapi kontainer dengan ukuran 20 feet dapat diletakkan di atas kontainer dengan ukuran 40 feet. Kontainer dengan ukuran 40 feet hanya diperbolehkan untuk diletakkan di atas kontainer dengan yang sama (lihat gambar 21).

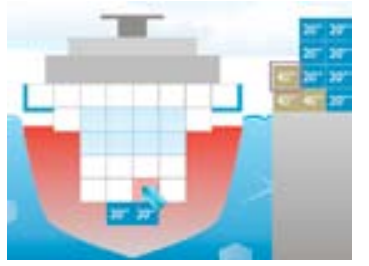

(a) Penataan kontainer 40 feet di atas kontainer 20 feet

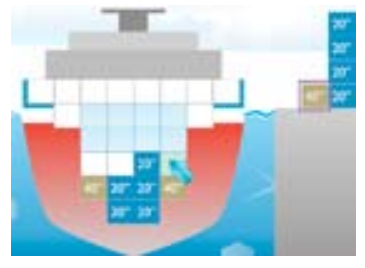

(b) Penataan kontainer 40 feet di atas kontainer 40 feet
Gambar 21. Aturan Penataan Berdasarkan Ukuran Kontainer 


\section{Aturan Penataan Kontainer Berdasarkan Kemiringan Kapal}

Penataan kontainer pada suatu state pastinya akan menghasilkan suatu kemiringan terhadap kapal. Jika kemiringan tersebut terjadi karena selisih berat dari suatu sisi yang melebihi toleransi kapal maka pemain harus meletakkan kontainer pada sisi yang lainnya. Pemain tidak diperbolehkan untuk menambah kontainer pada sisi yang mengakibatkan kemiringan dari kapal.

\section{Perhitungan Unnecessary Shifting}

Unnecessary shifting dari kontainer hanya terjadi untuk permasalahan penataan di atas level empat. Unnecessary shifting yang dihitung adalah shifting per kontainer yang berada di atas kontainer pada pelabuhan bongkar di mana kontainer yang menumpuk tersebut adalah kontainer pada pelabuhan berikutnya. Implementasi dari perhitungan unnecessary shifting dapat dilihat pada gambar 22 .

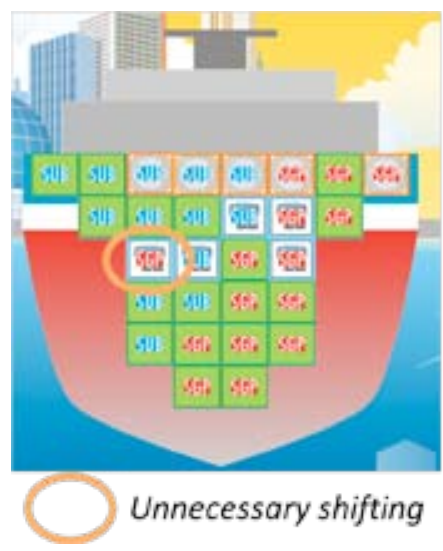

Unnecessaryshifting sebarwak 1 kontainer

Gambar 22. Perhitungan Unnecessary Shifting

Penilaian unnecessary shifting dari gambar di atas adalah sebanyak 1 (satu) kontainer. Kontainer yang mengalami unnecessary shifting dari gambar di atas adalah kontainer Singapura yang ditumpuk di atas kontainer dengan tujuan Surabaya.

\section{Aturan Evaluasi Status "Sukses" atau "Gagal"}

Penataan yang dilakukan oleh pemain akan diberikan status penataan sesuai dengan aturan yang telah ditentukan. Penataan akan diberi status gagal jika pemain tidak dapat menata semua kontainer di yard. Sistem game akan menghasilkan status penataan yang sukses jika pemain dapat menata semua kontainer ke dalam kapal.

\section{UJI EDUKASI DARI GAME}

Tahap uji edukasi dari game mencakup tentang perancangan soal dan uji edukasi dari game. Soal atau pertanyaan terkait dengan edukasi dari game disesuaikan dengan informasi yang diberikan oleh game. Uji edukasi dari game dilakukan dengan pre-test dan post-test untuk pertanyaan yang sama. Edukasi dari game akan dibuktikan secara statistik dengan uji paired-t test.

\section{Perancangan soal}

Soal dari game edukasi ini adalah soal pilihan ganda yang terkait dengan informasi yang diberikan pada game. Soal yang dibuat terdiri dari 13 soal dengan urutan soal yang disesuaikan tingkatan atau level yang terdapat dalam game. Ada beberapa alternatif dalam pembuatan soal, tidak hanya pilihan ganda, yaitu esai, dan pernyataan benar atau salah. Alternatif pilihan ganda dipilih karena dapat mempermudah penilaian edukasi dan juga dengan adanya pilihan ganda tingkat kesulitan dari soal relatif sedang karena adanya pilihan jawaban (salah) yang relatif mendekati jawaban yang benar.

\section{Uji Edukasi}

Uji edukasi perlu dilakukan agar sebuah game dapat dikatakan bahwa game tersebut dapat meningkatkan pengetahuan dari pemain terhadap suatu permasalahan. Uji edukasi yang dilakukan adalah pre-test dan post-test. Pre-test adalah uji pengetahuan dari pemain sebelum memainkan game sedangkan post-test adalah uji pengetahuan dari pemain setelah memainkan game. Soal dari pre-test dan post-test yang diberikan adalah sama. Hal yang akan diperbandingkan adalah jumlah nilai benar dari test yang diberikan. Hasil dari uji edukasi dapat dikatakan bahwa game dapat meningkatkan pengetahuan pemain jika perbedaan jumlah nilai benar dari test yang diberikan berbeda secara signifikan berdasarkan pada uji statistik.

Dalam uji edukasi ini akan dilakukan uji paired- $t$ dengan faktor permainan game. Pemain akan mengerjakan soal yang telah disebutkan di atas sebelum dan sesudah memainkan game. Yang akan dibandingkan dalam uji anova ini adalah jumlah jawaban benar dari soal dengan faktor treatment permainan game. Game akan dinyatakan memiliki faktor edukasi jika jumlah jawaban benar dari pemain berbeda secara signifikan berdasar uji statistik dengan menggunakan paired-t test.

Responden dari game ini ada 15 orang yang diambil dengan metode judgment sampling di mana peneliti mengetahui tingkat pemahaman dari responden terkait dengan penataan kontainer di bay kapal. Responden mengerjakan soal yang diberikan sesuai dengan ketentuan dari peneliti. Hasil dari uji edukasi terhadap responden dapat dilihat pada tabel 2 . 
Tabel 2. Hasil Uji Edukasi terhadap Responden

\begin{tabular}{clcc}
\hline \multirow{2}{*}{ No } & \multicolumn{1}{c}{ Responden } & \multicolumn{2}{c}{$\begin{array}{c}\text { Jumlah soal yang } \\
\text { berhasil di jawab }\end{array}$} \\
\cline { 3 - 4 } & & Pre-Test & Post-Test \\
\hline 1 & Arum Puji Lestari & 3 & 12 \\
2 & Titi Anindhita & 0 & 13 \\
3 & Putri & 0 & 13 \\
4 & Worosita Mulyaninglisti & 1 & 13 \\
5 & Habib Hamidi & 1 & 13 \\
6 & Kusbiantoro & 2 & 13 \\
7 & Nadia Aulia Arifin & 0 & 13 \\
8 & Savira Evany & 3 & 12 \\
9 & Nadya Rahmaviany & 1 & 13 \\
10 & Widha Kusuma & 2 & 12 \\
11 & Ratih Ardia Sari & 3 & 13 \\
12 & Indah Baroroh & 2 & 13 \\
13 & Hutama Purwananta & 2 & 12 \\
14 & Agung Puguh & 2 & 11 \\
15 & Andra Wibisono & 3 & 13 \\
\hline
\end{tabular}

Hasil dari uji edukasi terhadap responden tersebut diolah dengan menggunakan uji paired-t test untuk mengetahui apakah game yang dibuat dapat memberikan edukasi terhadap pemainnya.

Hipotesis dari uji paired-t test yang akan dilakukan adalah:

$\mathrm{H}_{0}=$ Game yang dibuat tidak memberikan edukasi terhadap pemain

$\mathrm{H}_{1}=$ Game yang dibuat memberikan edukasi terhadap pemain

Hipotesis awal diterima jika $\mathrm{p}$ - value $\geq 0.05$ dan hipotesis tandingan diterima jika $\mathrm{p}-$ value $<0.04$. Perhitungan dari paired-t test terkait dengan uji edukasi di atas (tabel 3) yaitu:

Tabel 3. Rataan Sampel

\begin{tabular}{lrr}
\hline & Pre-test & Post-test \\
\hline Rata-rata & 1,666667 & 12,6 \\
Standar deviasi & 1,112697 & 0,6324555 \\
Jumlah sampel & 15 & 15 \\
Ho & 0 & \\
df & 14 & \\
t Stat & $-28,4871$ & \\
p-value (two-tail) & $8,52 \mathrm{E}-14$ & \\
t Critical two-tail & 2,144787 & \\
\hline
\end{tabular}

Dari perhitungan paired-t test yang telah dilakukan (tabel 3) diperoleh p-value $<0.05$ sehingga kesimpulan yang diambil adalah tolak $\mathrm{H}_{0}$ dan nyatakan bahwa game yang dibuat memberikan perbedaan yang signifikan terhadap pengetahuan pemain terkait dengan permasalahan penataan kontainer di bay kapal.

\section{SIMPULAN}

Berdasarkan perancangan dan pengujian serta analisa dalam penelitian ini, maka kesimpulan yang diperoleh yaitu:

1. Dengan perancangan dan implementasi yang telah dilakukan, penelitian ini berhasil membuat suatu perangkat lunak berupa game edukasi untuk penataaan kontainer di bay kapal yang diberi nama StowaGame. StowaGame telah mampu menggambarkan permasalahan penataan kontainer di bay kapal dengan simplifikasi yang telah ditentukan.

2. Uji paired-t test terhadap game menghasilkan $p$-value $<0.05$. Hal ini dapat diartikan bahwa perangkat lunak yang dibuat mampu memberikan edukasi terhadap pemain game.

\section{DAFTAR PUSTAKA}

Ambrosino, D., Sciomachen, A., and Tanfani, E., 2004. Stowing a Containership: The Master Bay Plan Problem. Transportation Research A 38, 81-99.

Clark, D., 2006. Game and e-learning. Sunderland: Caspian Learning. URL:http://caspianlearning.co.uk. Akses terakhir: 01 April 2009.

Loomans, D. and Kohlberg, K., 1993. The Laughing Classroom. Kramer, H.J. Inc.

Marsh, T., Wong, W.L., Carriazo, E., Nocera, L., Yang, K., Varma, A., Yoon, H., Huang, Y., Kyriakakis, C., and Shahabi, C., 2005. User Experiences and Lessons Learned from Developing and Implementing an Immersive Game for the Science Classroom. Proceedings of HCI International 2005, Las Vegas, Nevada, USA. 